\title{
La plebe y los judíos La construcción de un mito histórico en la España del siglo XIX
}

\author{
Roberto LÓPEZ-VELA * \\ Universidad de Cantabria
}

La muerte de Fernando VII, el acceso al trono de Isabel II, junto a diversas medidas, entre las que se encontraba la abolición de la Inquisición en 1834, estuvieron en la raíz de las grandes transformaciones entre las que se desarrolló la revolución liberal. Habitualmente, se ha considerado al Santo Oficio inoperante al menos desde el trienio liberal ${ }^{1}$, pero esto es sólo una parte de la realidad, porque, tras la Guerra de la Independencia, su fuerza ya no residió en su capacidad de acción, sino en la presencia intimidatoria de su alargada sombra. Se iniciaba la larga andadura de la polémica de la Inquisición como símbolo de una forma de entender España y su pasado, que tanta importancia tendrá en el siglo xix. No es casual que siendo el emblema del fanatismo religioso y de la decadencia de España, en los años siguientes a su abolición se publiquen pocas obras referentes al Santo Oficio. Incluso los que aparecieron corresponden a autores de escaso relieve con trabajos de divulgación de fuerte

\footnotetext{
*lopezro@unican.es

1 L. Alonso TEJAdA, El ocaso de la Inquisición (Madrid 1969); J. PÉrEz VILARIÑo, Inquisición y constitución en España (Madrid 1973); F. MARTí GILABERT, La abolición de la Inquisición en España (Pamplona 1975).
}

Sefarad 64 (2004) págs. 95-140

(c) CSIC

ISSN 037-0894 
contenido panfletario, cuyo patrón es la Historia crítica de la Inquisición en España, escrita por J.A. Llorente ${ }^{2}$.

Tras más de diez años de su abolición, los historiadores españoles comenzaron a conectar con el pasado oculto que con tanto empeño y eficacia el Santo Oficio había reprimido y después borrado de la memoria histórica. Y lo hicieron reivindicando historiográficamente la herencia judía frente a las corrientes reaccionarias que actualizaban el tópico del judío traidor a España para utilizarlo contra los liberales ${ }^{3}$. Significativamente, rastrear la aportación judía también era sumergirse en las dificultades para el triunfo del liberalismo en España, lo cual suponía hablar inevitablemente de la Inquisición. El propio peso de la historia colocaba a la Inquisición y lo judío en el centro de los debates políticos y de cualquier esfuerzo de análisis sobre el pasado nacional. Inevitablemente, una historia así construida habría de presentar una visión distinta de la que hasta entonces constituía la argamasa de la Monarquía Católica, campeona de la fe.

Efectivamente, la persecución de los judeoconversos fue la preocupación recurrente del Santo Oficio hasta mediados del siglo XVIII ${ }^{4}$. No puede sorprender que uno de los primeros esfuerzos de la historiografía liberal se dirigiese a redescubrir la presencia de esta minoría. Para los historiadores de la época era evidente que los judíos habían sido el pueblo deicida, pero esto no justificaba su persecución porque la propia naturaleza evangélica de la Iglesia lo había impedido históricamente. ¿Por qué la Inquisición española había perseguido a los «judíos» y cuáles habían sido sus consecuencias? ¿Por qué los grandes reyes de la historia nacional que se estaba

2 J. A. LloRENTE, Historia crítica de la Inquisición en España, 4 vols. (Madrid 1981). Para un análisis de la trayectoria de la historiografía sobre el Santo Oficio, vid. R. LóPEZ-VELA, «Historiografía inquisitorial, catolicismo y España. Análisis de una trayectoria historiográfica», en Historia de la Inquisición en España y América, eds. J. Pérez Villanueva y B. Escandell Bonet, vol. III (Madrid 2000) págs. 83-168.

3 G. Álvarez Chillida, El antisemitismo en España. La imagen del judio (18122002) (Madrid 2002) págs. 103 ss.

4 J. Caro Baroja, Los judios en la España Moderna y Contemporánea, 3 vols. (Madrid 1978). 
comenzando a pergeñar, los Reyes Católicos, habían fundado la Inquisición para perseguir a esta minoría y habían acabado expulsándoles de España? ¿Cuál había sido la importancia de los judíos en la historia patria? La Historia de los judios en España desde los tiempos de su establecimiento hasta principios del presente siglo ${ }^{5}$, escrita por el gaditano Adolfo de Castro y publicada en 1847, fue el primer libro en aparecer planteándose estas preguntas. Propiamente hablando, fue la primera historia de los judíos en España que pretendía dar cuenta de su trayectoria desde su establecimiento hasta su expulsión. Un año después se publicarían los Estudios históricos, políticos y literarios sobre los judios en España, de José Amador de los Ríos ${ }^{6}$.

\section{CUESTIÓN JUDÍA Y REVOLUCIÓN LIBERAL}

Hace algunos años, Pérez-Prendes señaló que la lucha contra el liberalismo y la «revolución» comportó en España un auge del antisemitismo. La equiparación entre judío y liberal fue una imagen operativa bastante utilizada por las corrientes más reaccionarias. De nuevo el judío era la encarnación del traidor escondido que busca la destrucción del orden y la ruina de España, justo lo mismo de lo que se acusaba a los liberales. La Constitución de 1837 y la de 1845

5 A. de Castro, La Historia de los judios en España desde los tiempos de su establecimiento hasta principios del presente siglo (Cádiz: Imprenta y litografía de la Revista Médica, 1847); vid. S. Palomero PlazA, «Historia de los judíos de España, por D. Adolfo de Castro (Cádiz 1847)», en Judaísmo hispano. Estudios en memoria de José Luis Lacave Riaño, ed. E. Romero, vol. II (Madrid 2002) págs. 819-826. Para una visión de conjunto sobre el conjunto de la historiografía de los judíos en España, vid. C. CARRETE PARRONDo, «Lo judío en la historiografía española: ausencias y contiendas», en Los judios en la España contemporánea, eds. U. MACIAS CAPón et al. (Cuenca 2000) págs. 121 ss.; J. L. LACAvE, «Los estudios hebraicos y judaicos en España, desde Amador de los Ríos hasta nuestros días», en Los judios en la España contemporánea, págs. 115-120.

6 J. AMADOR DE LOS Ríos, Estudios históricos, políticos y literarios sobre los judíos en España (Madrid 1848); vid. mi estudio «Judíos, fanatismo y decadencia. Amador de los Ríos y la interpretación de la Historia Nacional en 1848», Manuscrits 17 (1999) págs. 69-95. 
consagraron el catolicismo de la nación y conservaron las disposiciones discriminatorias contra los judíos recogidas en la Cédula Real de 1802, aunque aplicasen con laxitud sus disposiciones ${ }^{7}$. Se trataba de un antijudaísmo con una presencia judía francamente exigua. Hace años, Caro Baroja llevó a cabo interesantes consideraciones en torno a las descripciones que Borrow había realizado sobre los descendientes de judeoconversos que conoció en la década de 1830 en su viaje por España mientras intentaba divulgar la Biblia ${ }^{8}$. En su relato de estos personajes, más bien parece dar cuenta de arquetipos recreados al gusto romántico que de personas concretas. Excepto los chuetas mallorquines, no hay constancia de núcleos reconocibles de descendientes de esta minoría, y el número de judíos que se pudiesen haber instalado en las ciudades en la primera mitad del siglo no podía ser significativo. El primer contacto con los judíos sefardíes se produjo al filo de 1860 , cuando las tropas españolas toman Tetuan ${ }^{9}$.

El antijudaísmo español se desplegaba contra una huella histórica, un símbolo recreado, más que contra un grupo social concreto. En esta estrategia, la literatura y el publicismo tuvieron la máxima importancia. El romanticismo a través de la literatura recreó y puso en circulación nuevos rasgos atribuidos a lo judío. Fernán Caballero convirtió a los judíos en la expresión misma de la irreligión, la lectura y el liberalismo ${ }^{10}$. Paralelamente, se perfiló la imagen de los judíos como un pueblo sensual y voluptuoso que gracias a sus mujeres

7 J. M. PÉrez-Prendes Muñoz-Arraco, «El nuevo marco legal: de la Real cédula de 1802 a los acuerdos de 1992», en Los judíos en la España contemporánea, págs. 75-91.

8 G. Borrow, La Biblia en España (Barcelona 2001) págs. 190 ss. y 495 ss.; J. CARO BAROJA expresa su acertada valoración de esta obra en Historia de los judíos, vol. III, págs. 164-168. Este último autor proporciona valiosas pinceladas sobre la presencia de los judíos en la Península que resultan bastante interesantes: ibid., págs. 202 ss.

9 U. MACIAS CAPÓN, «Los cronistas de la Guerra de África y el primer encuentro con los sefardíes», en Los judíos en la España contemporánea, págs. 45-60.

${ }^{10} \mathrm{~J}$. Álvarez Barrientos, «Los judíos y su cultura en la producción literaria española del siglo XVIII: la construcción del tópico ‘judeo-masón-liberal' durante la Ilustración y el romanticismo», en Judíos en la literatura española, eds. I. M. HASSAN et al. (Cuenca 2001) págs. 292-293. 
podían seducir y perder a los cristianos ${ }^{11}$. Desde el publicismo cobraron todo su vigor las acusaciones contra la conspiración judeomasónica anticristiana ${ }^{12}$. Es en este contexto en el que surgió una historiografía liberal cuyo objetivo pretendió ser la restauración de la verdad histórica de la nación y, por tanto, el papel fundamental de los judíos en su pasado. La historiografía fue el instrumento de los liberales para reivindicar el fenómeno judío en el pasado de España, frente a la propaganda o la literatura de inspiración reaccionaria.

La obra de Castro fue un hito importante en el esfuerzo por recuperar un pasado nacional «sin mentiras», por dar una visión crítica y «real» de esa España que se había fraguado a través de la represión religiosa durante siglos. Para Castro, como lo será después para Amador de los Ríos, cuanto sucedió en torno a los judíos es un eje central para entender los destinos históricos que en un día ya lejano tomó la patria. Comprenderlo, crear una memoria histórica entre los españoles capaz de asimilar e identificarse con su pasado como nación, resultaba para ellos y para el conjunto de la historiografía liberal ${ }^{13}$ la mejor forma de crear ciudadanos conscientes de las contradicciones de una herencia impregnada de fanatismo. Era el aprendizaje para ser capaz de encarar la construcción de una España liberada de sus cargas atávicas y oscurantistas. En este esfuerzo, tanto Adolfo de Castro como Amador de los Ríos tuvieron el indudable mérito de haber colocado la herencia hebrea en el centro de la historia nacional que estaba comenzando a escribirse. Adolfo de Castro y Amador de los Ríos abrieron con sus libros el camino para situar a la comunidad judía en lugar destacado a la hora de entender la identidad de los españoles. Más allá de la calidad y las aportaciones de sus obras, los efectos polémicos e historiográficos de semejante iniciativa se han dejado sentir hasta fechas bien recientes.

\footnotetext{
${ }^{11}$ P. FERNÁNDEZ, «La literatura del siglo XIX y los orígenes del contubernio judeo-masónico-comunista», en Judíos en la literatura española, págs. 304 ss.

${ }^{12}$ G. Álvarez Chillida, El antisemitismo en España, págs. 108 ss

${ }^{13}$ P. Cirujano Marín et al., Historiografía y nacionalismo español: 1834-1868 (Madrid 1986); J. Álvarez JunCo, Mater Dolorosa. La idea de España en el siglo XIX (Madrid 2001); C. P. BoyD, Historia Patria. Política, historia e identidad nacional en España: 1875-1975 (Barcelona 2000); I. Fox, La invención de España (Madrid 1997); C. FoRCADELL (ed.), Nacionalismo e historia (Zaragoza 1998).
} 


\section{AdOLFO DE CASTRO, HISTORIADOR DE LOS ASPECTOS MÁS NEGROS DE LA HISTORIA ESPAÑOLA}

Sin duda, la fama de personalidad atrabiliaria y de falsario que acompañó a Adolfo de Castro desde su juventud, a partir del suceso del Buscapie ${ }^{14}$, ha contribuido a ensombrecer su obra y su influencia. Efectivamente, lo que luego definió como una «muchachada», la publicación de una supuesta obra del mismo Cervantes en la que se defendía de quienes le atacaban por la primera edición del Quijote, constituyó un acontecimiento literario de primera magnitud a principios de 1848. Hacía meses que se venía anunciando el evento, y en ellos el autor preparó con meticulosidad su impostura ${ }^{15}$. El éxito editorial fue enorme: Ravina Martín calcula en 3.000 ejemplares la tirada de la primera edición, y en pocos meses el libro fue traducido y publicado en Francia, Inglaterra y Estados Unidos ${ }^{16}$. Evidentemente, desde el principio la polémica acompañó su publicación, y numerosos eruditos negaron la autenticidad de la obra, tildando a su autor de falsario. Ticknor, Gallardo y otros desenmascararon poco después la superchería. Castro había publicado su Historia de los judios apenas unos meses antes de la aparición del Buscapié, seguramente cuando ya tenía muy avanzada la «muchachada». Un año después, coincidiendo con la polémica en torno al Buscapié, aparecieron los Estudios históricos, políticos y literarios sobre los judios en España de Amador de los Ríos. Su superior calidad y el desprestigio en que había caído Adolfo de Castro contribuyeron a que se utilizase bastante más la obra de Amador de los Ríos.

En 1846 Adolfo de Castro publicaba El Conde-Duque de Olivares y el rey Felipe $I V^{17}$; al año siguiente aparecía la Historia de los Ju-

\footnotetext{
${ }^{14}$ Y. Vallejo MarqueZ, Adolfo de Castro (1823-1898). Su tiempo, su vida y su obra (Cádiz 1997); M. RAvina MARTín, Bibliófilo y erudito. Vida y obra de Adolfo de Castro (1823-1898) (Cádiz 1999).

${ }^{15}$ C. A. BARRERA, El Cachetero del Buscapié. Resumen del hecho y de las razones críticas que evidencian la falsedad de El Buscapié de D. Adolfo de Castro y otro tal que se mintió en el pasado siglo (Madrid 1849).

${ }^{16}$ M. Ravina Martín, Bibliófilo y erudito, págs. 37-38.

${ }^{17}$ A. DE CASTro, El Conde-Duque de Olivares y el rey Felipe IV (Cádiz: Imprenta, Librería y Litografía de la Revista Médica, 1846).
} 
díos; en 1851, la Historia de los protestantes españoles y de su persecución por Felipe $I^{18}{ }^{18}$; y en 1852, el Examen filosófico sobre las principales causas de la decadencia de España ${ }^{19}$. En seis años, cuatro obras en las que tocaba los argumentos que fueron recurrentes entre los historiadores liberales para explicar las razones de la decadencia nacional ${ }^{20}$, es decir, los problemas de su propio presente histórico. Todas ellas son obras publicadas en Cádiz, lo cual puede dar la falsa sensación de tratarse de un autor cuyo ámbito de influencia se reduce a su ciudad. Es cierto que es un autor que vivió siempre muy ligado a su ciudad y que su labor como historiador comenzó precisamente historiando Cádiz y Jerez, pero aun estando alejado de los círculos más influyentes de Madrid, su obra tuvo una indiscutible repercusión en España y fuera de ella, especialmente en estos años iniciales. Es cierto que los historiadores de mayor peso apenas lo citaron posteriormente y que, cuando lo hicieron, no dudaron en mofarse de sus «muchachadas». Menéndez Pelayo, en cambio, le trata con gran respeto en su Historia de los heterodoxos, calificándole de amigo. Refiriéndose a su Historia de los protestantes y a los excesos allí contenidos, afirma: «pública y solemnemente los ha reconocido su autor, en diversas ocasiones, elevándose y realzándose de esta suerte a los ojos de su propia conciencia, a los de todos los hombres de corazón e inteligencia sanos, y a los de Dios sin duda, a quien ha ofrecido como una expiación sus brillantes producciones posteriores» ${ }^{21}$. No se puede negar que A. de Castro fue un personaje peculiar ${ }^{22}$ que despertó notable curiosidad a lo largo de su vida y cuya influencia trascendió con mucho su Cádiz natal.

${ }^{18}$ A. DE CASTRO, Historia de los protestantes españoles y de su persecución por Felipe II (Cádiz: Imprenta, Librería y Litografía de la Revista Médica, 1851).

${ }^{19}$ A. DE CASTRO, Examen filosófico sobre las principales causas de la decadencia de España (Cádiz: Imprenta de Francisco Pantoja, 1852).

${ }^{20}$ R. GARCía CÁrCEL, La leyenda negra. Historia y opinión (Madrid 1992); G. PASAMAR AlZURíA, «La configuración de la imagen de la "Decadencia española" en los siglos XIX y XX. (De la "historia filosófica" a la historiografía profesional)», Manuscrits 11 (1993) págs. 183-214.

${ }^{21}$ M. MENÉNDEZ PELAYO, Historia de los heterodoxos españoles, vol. I (Madrid 1986) págs. 33-34.

${ }^{22}$ S. Palomero PlazA, «Historia de los judíos de España», pág. 825. 
Las obras de Castro tuvieron en algunos casos (Historia de los protestantes) varias ediciones, y fueron traducidas inmediatamente a diferentes lenguas. En concreto, la Historia de los judíos fue traducida al inglés en 1851; la Historia de los protestantes, también al inglés, en 1851, al holandés en 1854 y al alemán en 1866; y el Examen filosófico, al inglés en $1853^{23}$. Seguramente, fue superior el éxito de Adolfo de Castro en Inglaterra y en Alemania que en la misma España. Curiosamente, los Estudios de Amador de los Ríos tuvieron en la época una edición en español, siendo traducidos al francés.

En el ochocientos se tradujeron al castellano muchas obras de historia de autores extranjeros, aunque fueron pocos los historiadores españoles traducidos a lenguas extranjeras. Se puede afirmar que Castro fue uno de los que más claramente gozó de este raro privilegio y, además, de forma reiterada. Un caso excepcional que debe ser valorado en su justa medida, teniendo en cuenta que no sólo se le tradujo un libro o sobre un tema, sino todo un conjunto de obras que abordaban los aspectos más escabrosos de la historia hispana: aquellos en torno a los que se estaba renovando en profundidad la leyenda negra. No es exagerado considerar que, para cualquier autor extranjero, la obra de Castro, traducida a diversas lenguas bastante más difundidas que el castellano, fue a lo largo del ochocientos una de las pocas posibilidades de conocer a un «historiador» español de su contemporaneidad. Creo que la aportación de A. de Castro a la configuración de la idea de España y los españoles en la Europa de su época es digna de consideración.

España había sido fundamental en la modernidad. Gran parte de las naciones europeas se habían construido luchando contra España o bajo su gobierno y, por tanto, en su pasado habían sido también esenciales los reyes de la dinastía austriaca. La historia de España importaba a los autores nacionales, pero también a los historiadores de las naciones emergentes de Europa. No es extraño que sobre los

\footnotetext{
${ }^{23}$ Para las traducciones de A. de Castro, vid. Y. VAllejo Márquez, Adolfo de Castro, pág. 200; M. RAvinA MARTín, Bibliófilo y erudito, págs. 167-169.
} 
reyes de la dinastía austriaca escribiesen muchos historiadores europeos del ochocientos, bastantes de los cuales fueron traducidos al castellano. Entre estos autores los hubo de gran rigor académico, pero también propagadores de la leyenda negra que apenas superaban el libelo, y bastantes de los cuales, directa o indirectamente, fueron deudores de las interpretaciones de A. de Castro. Es más que probable que, por esta vía de influjo en autores extranjeros que posteriormente fueron traducidos al castellano, la obra del autor gaditano, lo citen o no, tuviese más eco entre los historiadores españoles, especialmente anticlericales, que a través de la lectura directa de sus libros en castellano.

La dedicación de Castro a las materias históricas no fue nada despreciable, aunque en su larga trayectoria esencialmente se preocupó de cuestiones ligadas a materias literarias ${ }^{24}$. Esto es algo que se aprecia con mayor claridad a medida que transcurre su biografía, porque sólo en su juventud manifestó una clara inclinación a tratar aspectos de la historia española. Estos años de intensa preocupación histórica coincidieron con el gran despliegue de la historiografía liberal empeñada en rescatar del olvido los pasajes de la historia hispana más ensombrecidos por el «fanatismo». En estos años cruciales, A. de Castro fue uno de los autores más señalados en esta tarea. En mi opinión, este empeño es uno de los más significativos y fundamentales del autor, por mucho que quedase oculto entre los dislates y «muchachadas» que protagonizó en esta coyuntura. Resulta sorprendente constatar la escasa trascendencia que los recientes estudiosos de la obra de Castro dedican a su obra historiográfica. No han valorado en su justa medida su importante influencia dentro del proyecto liberal de construir una interpretación del pasado español y la repercusión que tuvo el autor en Europa y en España.

\footnotetext{
${ }^{24}$ Vid. el «Catálogo Bibliográfico» de la obra de A. de Castro, seguramente el más completo, llevado a cabo por M. RAvina MARTín, Bibliófilo y erudito, págs. 133 ss. También es interesante el que realiza Y. VAllejo MárqueZ, Adolfo de Castro, págs. 115 ss.
} 


\section{El OBJETIVO DE LA HiSTORIA DE LOS JUDÍOS EN ESPAÑA}

Adolfo de Castro escribe su Historia de los judios en 224 páginas, más un peculiar apéndice documental sobre los jesuitas que nada aporta a la obra y que sólo demuestra el anticlericalismo del autor en estos años ${ }^{25}$. Abre el libro dando cuenta del carácter militante de su proyecto, advirtiendo al lector de las consecuencias de su propuesta, al tiempo que toma sus precauciones. Advierte que hablar de los judíos en España es introducirse en «una historia llena no de ilustres vencimientos, señaladas proezas y altos fines, sino de calamidades, conflictos, persecuciones, motines de la plebe, robos, incendios, destierros, muertes a fuego en públicos cadalsos, infamias de linajes, encarcelamientos, oprobios y otros rigurosísimos castigos» ${ }^{26}$. Y es que para el autor las relaciones entre los españoles y los judíos hispanos no ayudan a comprender los hechos heroicos de los españoles, sino la historia de las injustas víctimas que a través de la historia han ido generando los españoles.

Él también está dispuesto a cantar las glorias patrias, pero en su opinión hay un «error» importante «en todos nuestros historiadores al narrar la vida de los reyes, y es que miden las buenas acciones de ellos y el provecho con el buen gobierno dieron a sus vasallos por las batallas que vencieron, por las ciudades que ganaron y por las glorias que en sus empresas militares consiguieron». Sí, todo esto es importante, pero cuando sólo sirven para narrar batallas, marchas y contramarchas, «molestan los entendimientos por ser tan repetidas y enfadosas» ${ }^{27}$. No explica lo que para él debe ser la historia o cómo debe escribirse, pero esto no le impide construir su Historia de los judios como un contrarrelato de las historias nacionales que se estaban escribiendo en aquellos años, basadas en la exaltación de las glorias nacionales ${ }^{28}$. Una posición muy distinta a la que mantendrá

\footnotetext{
${ }^{25}$ La explicación de las razones para incluir tan singular apéndice se pueden encontrar en Historia de los judios, pág. 164.

${ }^{26}$ Historia de los judios, pág. 7.

${ }^{27}$ Historia de los judios, pág. 126.

${ }^{28}$ P. Cirujano Marín et al., Historiografía y nacionalismo español.
} 
Amador de los Ríos, que es bastante más respetuosa e, incluso, muy preocupada por proteger a algunos hitos «gloriosos» demasiado expuestos a la crítica. La posición de ambos autores respecto a la actuación de los Reyes Católicos, por ejemplo, será suficientemente paradigmática de esta distinta actitud.

En la Historia de los judíos, el lector encuentra la explicación de aquello que ha hecho de los españoles un pueblo con una idiosincrasia propia. Según el autor $-y$ en esto coincidirá Amador de los Ríos-, los siglos de convivencia y tensiones entre las dos comunidades han marcado la historia nacional y una forma de ser de los españoles, que posteriormente se ha proyectado en otros terrenos. Amador de los Ríos hace un gran esfuerzo por aproximarse a la trayectoria de la comunidad judía recogiendo la obra de sus destacados intelectuales y dando cuenta de sus aportaciones al conocimiento. Para él, su idiosincrasia como pueblo, su identidad religiosa y su aportación a la humanidad, se reflejan claramente en el trabajo de sus intelectuales y a través de ellos define al pueblo judío ${ }^{29}$. En cambio, Adolfo de Castro apenas si se detiene en el estudio de los intelectuales hebreos, porque no le interesa su itinerario cultural, aunque en su análisis sea fundamental el recurso a obras literarias. En realidad, no dedica esfuerzo a analizar a la comunidad judía, su religión, ritos, costumbres, etc. Ni tan siquiera se detiene en alguna de las grandes figuras de los hebreos hispanos. Más que de la historia de los judíos, trata de la de los «españoles» a través de sus relaciones con unos judíos vistos como una parte claramente diferenciada de la nación. Es decir, lo que le importa es la identidad de los españoles, no la de los judíos, y esta es la razón de ser que impregna cada pagina del libro.

Al escribir sobre los judíos, A. de Castro se proponía restablecer la verdad sobre la importancia del pueblo judío en la construcción de España, dejando claro desde el principio que «ni soy judío ni

${ }^{29}$ R. LÓPEZ VELA, «Judíos, fanatismo», págs. 75-77. 
vengo de judaizantes». Una declaración nada ociosa en la época teniendo en cuenta las acusaciones que soportó Mendizábal por su pasado converso ${ }^{30}$. Lo judío seguía teniendo una gran carga oscura y atávica de anticatolicismo y antiespañolismo perfectamente visible en los círculos liberales. El restablecimiento de la verdad sobre los judíos implica «sacar el entendimiento de las cárceles en que está aprisionado desde la niñez, limpio de corrupción y del veneno que bebió en las doctrinas del vulgo y en la ignorancia de sus padres y maestros» ${ }^{31}$. Durante el reinado de los Reyes Católicos, ningún escritor se atrevió a escribir la verdad, y desde entonces, generạción tras generación, han expresado el odio acumulado contra este pueblo maldito. Cuanto se sabe sobre esta comunidad es el resultado de la mentira y la manipulación con la que se ha alimentado al pueblo español durante siglos, imposibilitándole conocer lo que fue su pasado. Teóricamente, su proyecto consiste en demostrar las aportaciones de los judíos a los avances intelectuales y científicos, al tiempo que desmontar la falsedad de las acusaciones que se han vertido sobre ellos. Un esfuerzo que para él constituye la mejor forma de desvelar los secretos de la historia nacional que es sistemáticamente identificada con la de Castilla. En la Historia de los judios apenas si se menciona la existencia de los reinos de la Corona de Aragón durante la Edad Media, siendo difícil y circunstancial encontrar en cualquier momento referencias a ciudades o reyes que no sean de Castilla.

La perspectiva de la Historia de los judios en España gira en torno a lo que es su punto final, el reinado de los Reyes Católicos, aunque en cuanto rodea a la invasión árabe se ve también otra de las coyunturas decisivas de la historia patria. En la obra de Castro, ambos son los momentos estelares de la historia nacional. En función de resaltar ambas «tragedias», construye un libro de estructura marcadamente desigual. Los períodos en los que no hay grandes perse-

\footnotetext{
${ }^{30}$ J. Caro Baroja, Los judíos en la España Moderna y Contemporánea, págs. 199 ss.; G. Álvarez CHILlidA, El antisemitismo en España, págs. 116-118.

${ }^{31}$ Historia de los judíos, págs. 8-9.
} 
cuciones contra los hebreos son despachados por A. de Castro con evidente desgana, recurriendo a largas citas literarias o a una narración de anécdotas de poca o ninguna trascendencia.

El autor intenta la reivindicación de una visión distinta de la historia de España, destacando las nefastas consecuencias que se han seguido de aplicar una política fanáticamente católica. Como advierte desde el principio, la expulsión de los judíos fue un gran error, quizá la gran tragedia de la historia nacional. En su opinión, a esta dura medida se oponían razones de Estado que no hacían recomendable deshacerse de un grupo económica e intelectualmente tan valioso, sobre todo por lo desaconsejable de las persecuciones religiosas, «pues los monarcas bien podrán regir con las leyes de la fuerza los cuerpos de sus vasallos; pero no podrán sujetar los ánimos, porque más fácil cosa sería poner antes frenos a los vientos y hacer que volviesen atrás las corrientes de los ríos» ${ }^{32}$. A lo largo de la obra, el autor teje una desigual madeja en la que la razón de Estado, «las letras», los intereses económicos y la tolerancia marcan una lógica acorde con los principios liberales, en su opinión bien distinta de la que ha presidido el transcurrir de España a lo largo de la historia.

\section{El Planteamiento y la metodología de la Historia DE LOS JUDÍOS}

Sus fuentes no son rigurosas ni muy variadas. Utiliza algunas colecciones legislativas, como Las Partidas, crónicas y obras de historia de los siglos xvi y xvII, el Semanario Erudito de Valladares y algunos trabajos de Mayans y Ciscar ${ }^{33}$, aunque en la mayoría de los casos no se entretiene en citar o mencionar la crónica o la obra de la que ha extraído la información. No obstante, lo que maneja con mayor facilidad son las obras literarias, a las que recurre con gran frecuencia, vengan o no a cuento, para cubrir períodos o pasajes

${ }^{32}$ Historia de los judíos, pág. 8.

${ }^{33}$ Historia de los judios, pág. 33. 
concretos de los que tiene poca información. A veces dedica varias páginas a transcribir un poema, breve papal, carta, etc., que convierte en el centro de su demostración, por mucho que su contenido tenga poco o nada que ver con las valoraciones que realiza. Su esfuerzo en buscar noticias en las crónicas, e incluso su conocimiento de ellas, resulta bastante limitado.

Al igual que Amador de los Ríos, A. de Castro muestra un gran interés en desmentir las leyendas que hablaban de la presencia de los judíos en la Península Ibérica con anterioridad a la muerte de Cristo, aunque su intento resulte bastante más endeble que el de aquél. Es cierto que desmintió un conjunto de patrañas sobre la carta que los judíos españoles habían dirigido a Jerusalén para impedir que matasen a Jesucristo, algo a lo que según él habían dado credibilidad autores de tanto peso como Fray Prudencio de Sandoval, Arias Montano, Pellicer, Juan de Vergara y otros. También es cierto que entendió esta información dentro de una campaña iniciada por algunos autores desde el siglo xvi para lograr que «los judíos españoles (...) pareciesen menos aborrecibles a los ojos del vulgo» y para «mitigar también las cruelísimas persecuciones que en tiempos modernos sufrían del Santo Oficio» ${ }^{34}$. Pero no es casualidad que reproduzca íntegramente la falsa carta u otros documentos del mismo estilo ${ }^{35}$. Los autores «antiguos» y las leyendas que crearon o reprodujeron continúan siendo su marco de referencia, de forma que las noticias históricas del autor contribuyen a veces a dar pábulo a los «engaños» que pretende desechar. Así, habla de las campañas de Nabucodonosor en «Africa y España», desmintiendo que en éstas le hubiesen acompañado los judíos que a la sazón eran sus enemigos ${ }^{36}$. Es evidente que A. de Castro no se ha molestado en consultar las historias de España que por entonces estaban publicando autores

\footnotetext{
${ }^{34}$ Historia de los judíos, pág. 15.

${ }^{35}$ Y. BAER, Historia de los judíos en la España cristiana (Madrid 1998) pág. 16, trata el origen de las leyendas que surgieron en el siglo $\mathrm{x}$ en torno a la llegada de los judíos a la Península.

${ }^{36}$ Historia de los judíos, pág. 10.
} 
franceses e ingleses, y esto es algo que se percibe con nitidez a lo largo de todo el libro ${ }^{37}$. A estas alturas del siglo se tiene más y mejor información de la que Castro refleja y, cuando no se cuenta con noticias claras, la nueva historiografía utiliza la «conjetura» para intentar aproximarse a lo que sucedió. Así, cuando Amador de los Ríos se refiere al posible establecimiento de núcleos judíos en España antes de la época de Tito, algo sobre lo que no tiene noticias ciertas, deja claro que «sólo podemos ofrecer a nuestros lectores una opinión más o menos cuestionable, más o menos digna de crédito» ${ }^{38}$. Por esta razón, en sus Estudios históricos comienza a hablar de la presencia de los judíos en la Península a partir de la destrucción del Templo de Jerusalem. Evidentemente, A de Castro no es un historiador que rompa con la metodología de las crónicas. La «leyenda» o «las novelerías», como le gusta decir, siguen siendo un marco de referencia.

Su esfuerzo por depurar y contrastar la información resulta francamente escaso, siendo el análisis filológico el instrumento en el que más se apoya a la hora de verificar los documentos. Del mismo modo, resulta muy limitado su interés por presentar una secuencia seriada de hechos. De ello se deriva una narración muy desigual de los acontecimientos en función de su tesis, siendo frecuente que la exposición de esta última sea más prolija que el relato de los sucesos. Ante todo, el autor lleva a cabo a lo largo de su obra un ejercicio pedagógico destinado a convencer al lector de su lectura liberal de la historia nacional, y a este esfuerzo queda subordinado todo lo demás.

${ }^{37} \mathrm{C}$. ROMEY, Historia desde el tiempo primitivo hasta el presente, 4 vols. (Barcelona: Imp. de don Juan de Olivares, 1839-1845); E. RosseEuw SAINT-HILAIRE, Histoire d'Espagne depuis les primiers temps historiques jusque a la mort de Ferdinand VII (París 1844-1875); V. DU-HAMEL, Historia constitucional de la Monarquía española desde la invasión de los bárbaros hasta la muerte de Fernando VII (Madrid: Mellado Editor, 1848).

${ }^{38}$ Estudios históricos, pág. 8. Para un análisis de la metodología de la nuevas corrientes historiográficas, vid. G. PASAMAR ALzURía, «La invención del método histórico y la historia metódica en la España del siglo XIX», Historia Contemporánea 11 (1994) págs. 183-213. 
En su filosofía de la historia, junto al liberalismo, concede la mayor importancia a su negativa concepción antropológica del hombre, caracterizado como voluble y en el que destaca «cuan flaca y ciega es la razón humana, y cuan fácilmente tuerce y lleva la condición de los mortales a odiar lo más amado y amar lo más aborrecido. Porque como los pareceres de los hombres están casi siempre regidos por la fuerza de las pasiones, tienen más mudanzas que el mar o que la luna y del mismo modo que arrojan en el polvo todo lo que no camina ajustado a sus opiniones, ponen sobre las estrellas cuanto viene a conformarse con su natural condición» ${ }^{39}$. Sólo los hombres sabios y a veces los reyes, los nobles o los obispos, la elite en cualquier caso, puede escapar de esta subordinación a las bajas pasiones. Estas últimas son las únicas pasiones que le interesan y de las que da cuenta y que, por supuesto, son patrimonio del «vulgo ignorante». Las consecuencias de este «comportamiento» marcan la historia nacional, y de ello proporciona abundantes testimonios a lo largo del libro. Del mismo modo, las «novelerías no tienen otro fundamento que las hablillas y consejas del vulgo» ${ }^{40}$, que es el depositario natural de todo tipo de falsas noticias sobre los judíos destinadas a exacerbar los ánimos. En la pluma del autor, la plebe aparece habitualmente convertida en un animal incontrolable dominado por instintos primarios y sentimientos de odio, avaricia o venganza, alimentados por rumores o novelerías, que la convierten en un sujeto colectivo voluble de extrema peligrosidad.

En la Historia de los judíos hay diversas fuerzas motrices, colectivas o individuales, y en todas ellas intervienen las pasiones humanas. Son la Monarquía, la Iglesia, la plebe, los judíos..., aunque no todos intervienen en cada momento. Para ser exactos, durante largos períodos, desde la invasión árabe hasta la llegada de los Trastámara, se puede olvidar de la existencia de la Iglesia o la plebe. Castro no siente la necesidad de dar cuenta de forma sistemática de la evolución de las fuerzas que, según él, han movido la historia de España. Sin embargo, es frecuente encontrar prolijos relatos de un suceso en

\footnotetext{
${ }^{39}$ Historia de los judíos, pág. 17.

${ }^{40}$ Historia de los judíos, pág. 36.
} 
el que se pone de manifiesto la importancia del odio o el egoísmo en la actuación de los hombres. Es más, para dar cuenta de largos períodos introduce uno de estos relatos a través de un suceso sin ninguna trascendencia ${ }^{41}$, haciendo gala de un recurso narrativo de ficción, con nulo rigor historiográfico para los parámetros de la época ${ }^{42}$. Así, cuando cuenta a lo largo de varias páginas cómo se urde una intriga por parte de un grupo de judíos contra uno de su comunidad, se mueve entre un prolijo detallismo y la más evidente falta de precisión al explicar que decidieron «acusarlo de no se que débitos» ${ }^{43}$. La precisión nunca es una de las mayores preocupaciones del autor.

La historia para A. de Castro no es más que una sucesión de acciones protagonizadas por hombres que, al estar gobernados por sus intereses y sus pasiones, desbaratan los proyectos más racionales de los reyes o los destinos históricos. Es la fragilidad de la razón frente a la fuerza de las pasiones y la fortuna. A la hora de construir su obra, esta concepción le sitúa más cerca de los géneros narrativos de ficción que de la filosofía de la historia que por entonces dominaba el quehacer de los mejores historiadores. Amador de los Ríos, en sus Estudios históricos, políticos y literarios sobre los judíos en España, da una clara muestra de las posibilidades de esta historia filosófica ${ }^{44}$ y de su superioridad respecto al modelo narrativo de Castro, que en algunas ocasiones se encuentra más próximo a la crónica y en otras al folletín. Precisamente por esto, algunos de los pasajes de la Historia de los judios parecen sacados directamente de las páginas de un cronista medieval, que por supuesto no cita, mientras que en otros se acercan a la novela histórica panfletaria. En su afán por deshacer las «novelerías» con que distintos autores «antiguos» han rodeado la historia de los judíos, construye otra «novelería» u otra crónica, más acorde con los gustos narrativos y las preocupaciones de su época. Desde esta metodología hay que entender el lugar central de las largas citas literarias o los versos del cancione-

\footnotetext{
${ }^{41}$ El relato que hace del suceso del contador de Enrique II, Juzaf Pichón, resulta suficientemente elocuente: vid. Historia de los judios, págs. 67-71.

42 G. PASAMAR Alzuría, «La invención del método histórico».

${ }^{43}$ Historia de los judíos, pág. 67.

${ }^{44}$ R. LÓPEZ-VELA, «Judíos, fanatismo», págs. 73 ss.
} 
ro, dentro de una narración repleta de recursos efectistas para impactar al lector con su propagandismo liberal.

Propiamente, el autor no define con precisión si los judíos forman parte de la comunidad nacional o no. En esto es bastante menos preciso que Amador de los Ríos. Es más, a lo largo de sus páginas proporciona valoraciones contradictorias, pero todo hace indicar que, durante los más de mil años de convivencia, los ve como un cuerpo aparte en el marco de una relación en constante mutación, que es necesario seguir en su trayectoria. En algunos pasajes, especialmente cuando se trata de reivindicar su importancia económica e intelectual, se pregunta: «¿no eran españoles como nosotros? ¿El ser de diversa religión que los reyes y la mayor parte del pueblo les podía quitar la patria?» ${ }^{45}$. En cambio, en los numerosos pasajes de la obra en que habla del «exceso de libertad» en la que vivían los judíos, de su carácter «miserable», etc., los considera un cuerpo extraño en relación a unos españoles que tienen unos valores y actúan de forma bien distinta. Con ningún otro grupo «español» hace consideraciones semejantes. En la Historia de los judíos, éstos se manifiestan como un grupo compacto y sin fisuras, como a su vez aparece la plebe, el centro de gravedad de la «nación» española.

Podría decirse que en el libro el espacio de lo judío está más delimitado por la actuación de los «españoles» que por identidad religiosa o el comportamiento de los judíos. De hecho, no da cuenta de ritos, ceremonias, costumbres, etc., propias de los hebreos. ¿Cómo define a «los judíos»? ¿Son una comunidad, o un grupo definido por la raza o por la religión? Lo cierto es que los judíos, en cuanto tales, están perfectamente ausentes de la obra. No obstante, debe tenerse en cuenta que A. de Castro, pocos años después, para cuando escribe el libro citado anteriormente, Examen filosófico sobre las principales causas de la decadencia de España, ya no considera la presencia de los judíos y su relación con la comunidad cristiana un elemento esencial para entender la trayectoria de la nación y su posterior decadencia. En sus años jóvenes, el autor no se distingue por la firmeza de sus ideas.

${ }^{45}$ Historia de los judíos, pág. 124. 


\section{Hebreos, CATOLICISMO E ISLAM. UNA RELACIÓN TRUNCAdA}

Tanto para A. de Castro como para Amador de los Ríos, el período visigodo, especialmente las décadas precedentes a la invasión árabe, tiene un especial relieve. En los sucesos que se producen en estos siglos y en el comportamiento de los «pueblos» español y judío se prefiguran los rasgos definitorios de lo que será una larga trayectoria de desencuentros. En las distintas interpretaciones que desarrollan en estos primeros capítulos, ambos autores dejan claras las diferentes perspectivas desde las que analizan el conflicto entre las dos comunidades. No obstante, esta es la única parte que está más desarrollada en la obra de Castro que en la de Amador de los Ríos.

Para A. de Castro, el asentamiento de los judíos en España se produjo «en el año 70 de la era cristiana», tras la destrucción del templo de Jerusalén por el emperador Tito. A la hora de establecer el número de judíos en la Península en los momentos de la invasión árabe, el autor se desliza por sorprendentes disquisiciones que revelan su escaso virtuosismo y rigor en el manejo de asuntos históricos. Llegaron como una población derrotada, lo cual facilitó su asimilación y la convivencia con los «naturales». Al comienzo no había separaciones: sólo tras acumular riquezas, crearon sus barrios para establecer sinagogas y vivir con más comodidad. La consecuencia de esta evolución, para cuya demostración no presenta ninguna prueba, fue el que «por lo común los judíos que pasaron a España perdieron su lengua y se acomodaron facilísimamente a hablar la de la tierra». Esta fue la razón por la que en el español hay tan poca presencia de palabras de origen hebreo ${ }^{46}$. Según A. de Castro, a pesar de la suavidad con que se produjo la integración, los judíos pronto sufrieron el rechazo de los obispos hispanos. Reunidos estos en el concilio Eliberitano, les acusaron de intentar convertir a los cristianos, prohibiéndoles los tratos con ellos. Evidentemente, fueron los «españoles» los que tienen la iniciativa en las medidas represivas, siempre guiadas por la envidia o la negación de la libertad. Esta es una valoración bien distinta de la que planteará Amador de los Ríos ${ }^{47}$.

\footnotetext{
${ }^{46}$ Historia de los judios, pág. 22.

${ }^{47}$ Estudios históricos, págs. 9-10.
} 
La llegada de los bárbaros tuvo una notable importancia, no porque supusiese un cambio en la política sobre los hebreos, sino porque introdujo un sistema de gobierno distinto en la Península. En su opinión, los bárbaros salieron de sus casas «por pura ambición», y por «pura valentía se hicieron señores de las ajenas», pero para retener las tierras «usurpadas» usaron «el buen gobierno, con lo cual levantaban a las nubes su poderío, fundándolo en la verdadera obediencia y en el amor de los naturales, no en odios crueles y vanos intereses» ${ }^{48}$. Así, los godos no fueron «arrastrados en sus acciones por la intolerancia católica», sino por el deseo de conservar las conquistas. Esto no impidió que sus reinados estuviesen «llenos de odios fraternos y de todo genero de insultos y calamidades». A fin de cuentas, «como gente bárbara y rústica estaban dominados por la fuerza de sus pasiones», especialmente por la ambición, «de suerte que con furiosa presteza ejecutaban cuantas maldades le sugerían sus entendimientos desbocados».

A. de Castro desarrolla una amplia descripción de lo que entiende por «buen gobierno». Los godos desposeían a sus propios reyes y cometían todo tipo de traiciones y villanías con sus familiares, pero «eran pocos los daños que recibían los españoles». Esta es la curiosa explicación para justificar la pasividad frente a los godos de quienes define como sus antiguos compatriotas. Bien gobernados, les faltaban las fuerzas para rebelarse contra sus opresores y unos reyes cuya única legitimidad residía en su proclamación por el ejército y la plebe. A pesar de las declaraciones de A. de Castro sobre el buen gobierno de los godos, a lo largo de las páginas que les dedica no hay más que pruebas de lo contrario y ninguna de los aciertos.

En este marco de buen gobierno, en medio de la barbarie, los judíos pudieron gozar de tranquilidad y respeto hasta que Recaredo abjuró del arrianismo y se convirtió al catolicismo. Este fue el camino por el que «se abrió la puerta a las persecuciones del pueblo hebreo», prohibiendo el Concilio de Toledo del año de 589 el ejercicio de cargos públicos a los miembros de esta comunidad que tuviesen mancebas cristianas, etc. El autor no duda de las buenas intenciones

${ }^{48}$ Historia de los judíos, págs. 23-24. 
de quienes dictaron semejantes medidas para «embarazar los males que ocasionaban al cristianismo la demasiada libertad con que vivían en sus reinos los hebreos» ${ }^{49}$. En la Historia de los judíos, se da por buena la veracidad de los testimonios que en la época acusaban a los miembros de esta comunidad de intentar convertir a los cristianos y hacerse poderosos, entendiendo la necesidad de poner coto a estos «excesos». Sin embargo, lo que se niega es la validez de las medidas represivas que se adoptaron, porque a partir de aquí se creó una espiral de prohibiciones y expulsiones a los que no se convirtiesen al cristianismo, que sólo consiguieron exacerbar los ánimos de aquellos a quienes pretendían corregir. Vistos los problemas que engendraron, el autor afirma que los bárbaros e ignorantes actuaron como tales y no supieron rectificar, profundizando más y más en lo mismo. La combinación entre catolicismo y barbarie resulta fundamental en la Historia de los judios, aunque nunca lo señale explícitamente. En esta mezcla, el catolicismo fue el elemento dominante. En la antigüedad romana empezaron los problemas con la conversión al catolicismo, y lo mismo sucedió con los godos. Mientras estos sólo fueron bárbaros, a pesar de sus atrocidades, España estuvo «bien gobernada», ya que los judíos no fueron molestados. Con la conversión de Recaredo se combinó la tradicional política represiva del catolicismo con la barbarie, naciendo de este amasijo la esencia de los españoles. Este es un análisis muy distinto del que un año después publicará Amador de los Ríos culpando a los judíos y sus excesos de cuantas medidas tomaron los concilios de Toledo contra ellos ${ }^{50}$. En los Estudios históricos, este período destaca por ser en el que con más claridad se expresa la identidad perversa de los judíos y la necesidad por parte de los cristianos de adoptar medidas represivas.

El análisis del período anterior a la invasión árabe resulta en la Historia de los judios en un curioso antecedente de lo que ocurrirá setecientos años después con los Reyes Católicos. Se promulgaron

${ }^{49}$ Historia de los judíos, pág. 27.

${ }^{50}$ Estudios históricos, pág. 12. 
medidas represivas cada vez más intensas que pretendían separar a los judíos de los cristianos o expulsarlos, creando un gran número de «conversos» que no podían ser más que «judíos ocultos con las apariencias de cristianos» ${ }^{51}$. La situación se volvió tan opresiva para ellos, que perdieron la confianza en las leyes y en el futuro. Les forzaban a comer productos prohibidos, $\mathrm{y}$ «hablar con una persona no reputada por verdadero cristiano, les traía la perdida de su libertad y una perpetua esclavitud», sin que, por supuesto, pudiesen ejercer cargos públicos. Esto, en un marco en el que los hebreos podían ganar la amistad y colaboración de los nobles, obispos y poderosos en general, gracias a las relaciones que les facilitaban su industria y comercio. Ellos eran «los únicos o los más que traficaban entonces en España; puesto que la mayor parte de los godos, y muchísimos españoles, ya unidos a ellos por vínculos de parentesco y amistad, solo se ocupaban en envolver el reino en guerras civiles y en elegir y destronar reyes» ${ }^{52}$. Significativamente, en la Historia de los judios desaparecen las alusiones al buen gobierno en cuanto los godos se hacen católicos, momento en el que también comienza un intenso proceso de fusión que da lugar a un solo pueblo: el español.

Además de bárbaros y fanáticos, aparece una tercera cualidad: guerreros en permanente lucha. Con estas tres características, los españoles quedan definidos y estos tres rasgos explican sus actuaciones. Sin concretarlo, a medida que da cuenta del período visigodo, va identificando a godos y españoles hasta el punto de que a partir de la conversión de aquellos deja de hacer diferenciaciones entre ellos, algo que nunca ocurre con los judíos. Mientras los judíos y los españoles no se juntan nunca, aunque aquellos se conviertan, los bárbaros y los españoles dan lugar a un solo pueblo en cuanto se convierten los primeros. Sean pocos o muchos los judíos que se conviertan, los judíos siempre serán judíos. ¿Diferencia de religión, o de raza? Una pregunta a la que nunca contesta Castro, pero sí deja

\footnotetext{
${ }^{51}$ Historia de los judios, pág. 29.

${ }^{52}$ Historia de los judíos, págs. 30-31.
} 
muy claras las diferencias entre judíos y españoles. En la imagen que va pergeñando queda un esbozo en el que los judíos son industriosos, inteligentes, sensibles, con disposición a tomar iniciativas, aunque también traidores y con tendencia a actuar con más «libertad» de la que debiesen, cayendo frecuentemente en comportamientos irracionales guiados por la rabia o el odio. Los españoles, en cambio, aparecen retratados con precisión y rasgos indelebles, como unos guerreros semibárbaros, fanáticos en su forma de concebir la religión, dispuestos al robo, pero heroicos y dispuestos a desplegar su valor en campañas militares. La codicia forma parte de la esencia de ambos pueblos, pero mientras las bajas pasiones más destacadas entre los hebreos son la rabia y el odio, las de los españoles son la envidia, la crueldad, la violencia, la murmuración, la ignorancia, la superstición y, sobre todo, el fanatismo como forma de vivir la religión católica.

La invasión árabe y la ayuda que los judíos les prestaron es uno de los temas recurrentes de la historiografía del ochocientos que se limita a recoger las leyendas medievales. Sin duda, es uno de los grandes argumentos para demostrar el carácter traidor de los judíos y cómo sistemáticamente hicieron lo posible para destruir a los españoles. Por esta razón, no es sorprendente que A. de Castro se emplee a fondo en reinterpretar los precedentes que llevan hasta la invasión árabe para replantear el papel que desempeñaron los judíos y las motivaciones que les condujeron a prestar oídos a los invasores. Según el autor, la opresión extrema y sus grandes riquezas fueron las que llevaron a los judíos a conspirar para dar muerte al rey Ejica, junto a otros prelados y magnates del reino. Un aviso que lejos de ser entendido en lo que vaticinaba, desencadenó un arbitrario castigo. En este camino de continua presión represiva, desmiente que el reinado de Witiza fuese una excepción. Es cierto que Alfonso X así lo afirmó, siguiendo lo escrito por el obispo de Tuy en 1235 , pero éste se basó en las «consejas de la plebe o falsas relaciones de escritores árabes» ${ }^{53}$. Las pruebas de A. de Castro para sostener esta

${ }^{53}$ Historia de los judíos, pág. 35. 
refutación son cuando menos tan endebles como las que señalan lo contrario, pero para él lo esencial es demostrar la «insoportable opresión» sobre los judíos que impusieron los visigodos tras su conversión al catolicismo.

La sucesión de Witiza en favor de D. Rodrigo acentuó, para Castro, la división entre los visigodos, y permitió a los judíos una participación activa en ella. Los hijos de Witiza y otros nobles pasaron a África y pidieron ayuda a Muza para desplazar del poder a D. Rodrigo y los suyos. Muza pidió su colaboración a los judíos del norte de África para que pidiesen informes a los judíos españoles, y éstos se prestaron a proporcionar todo tipo de noticias sobre la situación de la Península. Aquí es donde se demuestra para el autor lo nefasto del excesivo rigor de los castigos y de las humillaciones, porque éstas nunca se perdonan y llenan los corazones de deseo de romper con el yugo: «Este fuego, aunque esté encubierto no necesita para levantarse más que un soplo del aire, y si los pueblos en sus motines o rebeliones, y más cuando han sido sin causa oprimidos, siguen los peores ejemplos, y se valen también de los peores, de los más atrevidos, de los más sangrientos y de los más feroces medios» ${ }^{54}$. Esta fue la «filosofía» profunda de los acontecimientos que facilitaron la invasión árabe y que en gran medida han presidido las relaciones entre españoles y judíos desde entonces, convirtiendo a los españoles en lo que han sido y en lo que son.

Desde el primer momento los judíos españoles, según Castro, negociaron con los árabes su colaboración, siempre y cuando se les permitiese vivir en su religión y se anulasen las medidas represivas. Una vez que los árabes aceptaron estas condiciones, quedó expedito el camino de la conquista. Para describir y ensalzar la heroica lucha de los españoles contra los árabes, recoge distintas crónicas, pero, a pesar de su grandiosidad, no es esto lo que le interesa, sino explicar por qué tan escaso número de árabes lograron dominar la Península.

${ }^{54}$ Historia de los judíos, pág. 36. 
Glorificación de un heroísmo tan grandioso como estéril, porque siempre se ejerce sobre causas que ya están perdidas o para seguir políticas fanáticas e injustas. Esta caracterización del heroísmo español será repetida frecuentemente en la obra de A. de Castro. Para él, los judíos eran «todos afectos a los conquistadores». Así, cuando tomaba las ciudades, Taric dejaba una pequeña guarnición de los suyos «fiando toda su seguridad de ellas en los muchos judíos en quienes había puesto las armas en las manos». De este modo pudo reducir Sevilla, Toledo, Córdoba y otras ciudades, llegando a encomendar la defensa de Granada solo a los judíos. En definitiva, este comportamiento de los árabes «demuestra claramente cuan corto era el número de cristianos que tomaron partido en favor de los muslines», y cómo los judíos fueron la pieza clave en el sometimiento de la Península a sus nuevos señores.

En la explicación de A. de Castro, la conclusión de esta secuencia de acontecimientos es muy clara: «estos fueron los frutos que cogieron los godos de las cruelísimas persecuciones hechas a los judíos sin considerar que las ofensas deben esperar la venganza de los ofendidos» ${ }^{55}$. Este es el colofón que le interesa, pero hay otras valoraciones no menos evidentes en su relato de las que no da cuenta, y cuya importancia no puede pasar desapercibida. En su comportamiento con los árabes deja plena constancia de lo ajenos que son los judíos a la nación española. Mientras fueron pocos los «españoles» que apoyaron a los invasores y muchos los que lucharon heroicamente contra ellos, la ayuda de los judíos, que según él actuaron como comunidad compacta, fue decisiva para llevar a cabo la conquista. En la Historia de los judíos se comprende lo que hizo esta comunidad hasta rozar la justificación, pero una vez más, siguiendo el tópico historiográfico dominante, se hace patente su carácter de grupo homogéneo de naturaleza traidora y enemigo de los españoles. Unos españoles descritos como fanáticos y violentos, carentes de mesura y sentido político, que con su acción brutal desencadenan los acontecimientos que acaban precipi-

${ }^{55}$ Historia de los judíos, págs. 43-44. 
tando la ruina y el desastre de la nación. Es decir, sólo los españoles, con su opresión sobre los hebreos, son los responsables de haber forzado a la traición a un pueblo de por sí poco firme y propenso a dejarse arrastrar por la venganza y el odio.

Este mismo papel «traidor» de los judíos es el eje de la interpretación de Amador de los Ríos en estos acontecimientos, aunque en este caso sólo la idiosincrasia de los judíos es responsable de sus propias decisiones ${ }^{56}$. El resultado final en ambos análisis supone culpar en gran parte a los judíos de la gran tragedia que en la historiografía del ochocientos suponía la invasión árabe. Al final, tanto A. de Castro como Amador de los Ríos reproducen y amplifican la propaganda antijudía que comenzó a utilizarse en Castilla a partir del siglo XII ${ }^{57}$ y que tan importante papel desempeñó en el rechazo a todo lo que tuviese que ver con lo judío durante la Edad Media y Moderna. No es exagerado señalar que a través de ambos autores se reprodujo en la historiografía liberal de estos años lo que había sido una pieza clave de la leyenda antisemita.

\section{ENTRE LA MONARQUía Y LA PLEBE, LA HISTORIA DE LOS JUDÍOS EN LA EDAD MEDIA}

Adolfo de Castro apenas habla de la dominación árabe ni de la naturaleza de los árabes en su libro, pero cuando lo hace, establece con nitidez algunas características de las que cabe deducir valiosas conclusiones. No importa que los árabes y los «españoles» habiten en la Península: los unos por su religión no son «españoles», mientras los otros lo son precisamente por su religión católica. En la pluma del autor, los árabes aparecen como portadores de una religión y una civilización tolerante y, por tanto, ajena a lo español, capaz de impulsar el progreso. Enfrente unos reinos cristianos ignorantes

\footnotetext{
${ }^{56}$ Estudios históricos, págs. 19-21.

${ }^{57}$ Y. BAER, Historia de los judíos en la España cristiana, pág. 22.
} 
tendentes a caer en los excesos del fanatismo religioso y la barbarie que son los mayores enemigos del progreso.

Muy «obligados» por los servicios de los judíos, los árabes les permitieron ejercer con libertad su religión y costumbres. El resultado fue que «muchos hebreos abandonaron la ley de Moisés cuando ninguna persecución recibían de mano de los reyes de España, cuando podían comerciar libremente», y cuando podían vivir tranquilamente dedicándose «descansadamente al estudio de las letras» ${ }^{58}$. No da pruebas de tan importantes conversiones al cristianismo, pero eso no le impide dejar claro que gracias a los judíos de España y a los que llegaron huyendo de las persecuciones de Oriente, que «eran sapientísimos», la España musulmana vivió un largo período de prosperidad y esplendor intelectual, siendo los judíos un motor esencial de este desarrollo. El mensaje es claro: donde hay libertad, florece la cultura. Una evolución que contrasta con la que se había producido bajo los reinados de los reyes godos católicos y que, apenas mitigada, continuó en los reinos cristianos del Norte. Es cierto que dada la penuria en la que se hallaban, en estos reinos cristianos hubo una mayor tolerancia hacía los judíos, pero siempre se mantuvo un notable recelo, que se prolongó a lo largo de la Edad Media con coyunturas marcadamente diferenciadas. Amador de los Ríos, en cambio, presenta una imagen heroica de la Reconquista, en la que los españoles adquirieron un hábito del combate, ligado a causas religiosas, cayendo algunas veces en el fanatismo, porque el espíritu de la época era fanático ${ }^{59}$.

En la Historia de los judíos, la Edad Media se reduce prácticamente al período que arranca de Alfonso X el Sabio y concluye con los Reyes Católicos. Efectivamente, si algo destaca del período medieval en la obra de Castro, además de la debilidad del análisis de los siglos previos a las grandes persecuciones de finales del siglo XIV, es la nueva orientación de la política de los reyes. Alfonso VIII

${ }^{58}$ Historia de los judios, pág. 49.

${ }^{59}$ Estudios históricos, pág. 23. 
y Fernando III el Santo, reyes de Castilla, inauguraron unas relaciones de mayor tolerancia hacia los judíos. Aquí hay un cambio fundamental, pero la plebe mantuvo el odio convirtiéndose en depositaria de la hostilidad tradicional. Las dinámicas sociales que aparecieron con los visigodos se mantienen con cambios sustantivos. Ahora la Monarquía se mueve en una tendencia más tolerante e integradora, mientras la plebe va radicalizando cada vez más su fanatismo.

El reinado de Alfonso X el Sabio tiene una notable importancia para A. de Castro, aunque bastante menor de la que adquirirá un año después en la obra de Amador de los Ríos. Para este autor, Alfonso $\mathrm{X}$ fue el prototipo de buen rey que, además, tuvo «un amor sin límites por las ciencias y las artes», algo que le convirtió de forma natural en protector directo de los judíos, estableciendo una relación armónica e ideal entre las diversas comunidades religiosas que habitaban la Península. Sin duda, para Amador de los Ríos Alfonso $\mathrm{X}$ ha quedado en la historia como el espejo de reyes ${ }^{60}$. En cambio, Castro ve dibujadas en este reinado las contradicciones que se muestran en los siglos siguientes. Según el autor, por el reconocimiento de los servicios prestados por los judíos, especialmente en el terreno intelectual, Alfonso x les confirmó en sus privilegios anteriores, «pero como también los hebreos andasen en su tiempo con sobra de libertad y cometiesen varios delitos», les prohibió que predicasen su religión y que convirtiesen a los cristianos ${ }^{61}$. Del mismo modo, les obligó a llevar signos distintivos, tal y como había mandado el Papa. No son estas disposiciones, no obstante, las que inspiraron la crítica de Castro a las acciones de este rey: «Yo admiro en don Alfonso el Sabio el varón más eminente de su siglo y el monarca que más ha trabajado en favor de la cultura de sus vasallos en todo linaje de artes y ciencias; pero no pudo con tan gran sabiduría ver muchas cosas sin ojos apasionados y sin ser arrastrado en muchas de sus acciones por la ignorancia vulgar en aquellos tiempos y aún en algunos de los

\footnotetext{
${ }^{60}$ Estudios históricos, pág. 31 ss.

${ }^{61}$ Historia de los judios, pág. 55.
} 
siglos que después de ellos han corrido» ${ }^{62}$. Efectivamente, el peso de la ignorancia del vulgo comenzó a adquirir un peso fundamental y determinante en la historia nacional, dejándose sentir en toda su intensidad hasta en el culto y buen rey que es Alfonso X.

Especial atención dedica Castro en su visión crítica de este reinado a dar cuenta de las leyes de Las Partidas, por las que se condena con la pena máxima a los autores de las supuestas crucifixiones de niños a manos de los judíos. Es esta una ley «fundada en las patrañas que entonces corrían en las lenguas de la supersticiosa y novelera plebe», e inventadas por «vejezuelas ignorantes» que «andaban de boca en boca por el ciego e ignorante vulgo» ${ }^{63}$. Una reiteración que es una constante a partir de este momento en la Historia de los judíos. A desmentir la crucifixión de niños en manos de los judíos dedica Castro un esfuerzo notable, que pone de relieve lo extendida que estaba esta leyenda todavía en 1847 y, por tanto, su empeño de ilustrado en combatir estas «novelerías». Efectivamente, es una «novelería» en la que continúa creyendo con algunos matices Amador de los Ríos. La argumentación de Castro está realizada desde el desprecio y el desdén hacia un «vulgo ignorante» que cree en todo tipo de supercherías y se mueve en la historia lleno de "pasión» para imponerlas a la nación. Desde esta altivez intelectual, desmiente el que los judíos «tienen rabo, porque como los sabios en su ley eran llamados rabíes» ${ }^{64}$. Semejante empeño sitúa con nitidez los anhelos y limitaciones de una obra que pretenden desmontar las «novelerías», más desde el sentido común de un intelectual liberal rebosante de desprecio a la plebe, que desde el esfuerzo de investigación histórica.

Tanto en la obra de A. de Castro como en la de Amador de los Ríos, a partir del reinado de Alfonso x el Sabio, el tratamiento se hace notablemente más sistemático y completo. En el repaso históri-

${ }^{62}$ Historia de los judíos, pág. 58.

${ }^{63}$ Historia de los judios, págs. 56-57.

${ }^{6+}$ Historia de los judíos, pág. 58. 
co de A. de Castro, Pedro I seguramente sea su monarca más apreciado, por mucho que dedique hermosas palabras a Alfonso X. Los datos que aporta no son muchos, pero sí destacados, y de entre ellos resalta una supuesta inscripción, que transcribe íntegramente, en la que los judíos de Toledo ensalzan al rey por la protección recibida. Entre este monarca y los judíos existió una profunda colaboración para hacer frente a las sublevaciones nobiliarias que terminaron por acabar con la vida del rey ${ }^{65}$. Un análisis que Amador de los Ríos desarrolla de forma más compleja, insistiendo en el resentimiento de los judíos frente a los cristianos, que les lleva a desconfiar siempre de sus vecinos, aun durante los años de D. Pedro, que tanto les protegió. El saqueo de la judería de Toledo en medio de la guerra civil entre D. Pedro y su hermano reveló lo fundado de este sentimiento ${ }^{66}$. En la Historia de los judios, la llegada de los Trastámara no supone un cambio apreciable de política hacia los hebreos. El cambio vino de la mano de la «enfurecida canalla» o «canalla desenfrenada», de la «plebe que dio en amotinarse contra las juderías para con capa de devoción y piedad, matar a sus habitantes y hacer muy buenas presas en sus haberes y haciendas» ${ }^{67}$. Estas son las palabras con las que el autor caracteriza las sublevaciones populares de 1391 que forzaron la conversión de muchos judíos. Amador de los Ríos, sin embargo, entiende que con Enrique II empezaron años de tolerancia hacia los desmanes del vulgo que expresaba en saqueos y ataques a las juderías su aversión por este grupo ${ }^{68}$. Por mucho que el rey pretendió corregir su error e imponer una política de control a la plebe, fue demasiado tarde, quedando abierto el camino hacia las persecuciones de finales del siglo. Al final, ambos coinciden en afirmar el creciente protagonismo del vulgo.

La revuelta popular de Sevilla de 1391 es la única que le interesa a Castro, y en torno a ella estructura su análisis. En esta ciudad se

\footnotetext{
${ }^{6.5}$ Historia de los judíos, págs. 60 ss.

${ }^{66}$ Estudios históricos, págs. 55-61.

${ }^{67}$ Historia de los judíos, pág. 79.

${ }^{68}$ Estudios históricos, págs. 61-62.
} 
puede comprobar que la Monarquía, las autoridades y buena parte de la nobleza hicieron todo lo posible para evitarla. Según el autor, el rey hizo lo que estuvo en su mano para evitar su extensión a otras ciudades, pero fueron el furor de la plebe, junto a la desidia de ciudades y la nobleza, los responsables de que el mal se contagiase por toda España. En cuanto las cosas se calmaron un poco, Enrique III no dudó en aplicar rigurosos castigos a cabecillas de Sevilla. Evidentemente, no fue sincera la conversión de numerosos judíos forzados por las circunstancias. Se hizo con los «medios que suelen emplear los tiranos de la tierra para conservar su poderío o para conseguir» sus propósitos ${ }^{69}$. Es decir, la plebe es la tiránica, con la pasividad de la nobleza y las ciudades, mientras que el rey mantiene una posición básicamente coherente.

Por primera vez, Castro sitúa en el mismo centro de la historia, como su protagonista principal, a la «feroz canalla» que actúa a través del «tumulto» como una fuerza ciega y destructora de los «mezquinos hebreos». Ya no es una fuerza de gran peso, como antes, sino la determinante y decisiva, capaz con su intervención de cambiar el curso de los acontecimientos. El motor de estos hechos, además de la codicia y la ignorancia del vulgo, es la predicación de algunos eclesiásticos, como el arcediano Fernando Martínez de Sevilla ${ }^{70}$. Una combinación que a partir de ahora se repetirá con frecuencia en la exposición de Castro.

La valoración de la Iglesia resulta más compleja. Es cierto -dice A. de Castro- que hay «malos clérigos» o «frailes avarientos» ${ }^{71}$, pero hay otros que aplacaron los ánimos y que, como San Vicente Ferrer, predicaron a los judíos intentando llevarlos por el «camino de la verdad por buenas palabras, por vivas y apretadas razones y

${ }^{69}$ Historia de los judios, pág. 83.

${ }^{70}$ Y. BAER, Historia de los judíos en la España cristiana, págs. 531 ss., presenta una imagen de los sucesos de 1391 que difiere notablemente de lo expuesto por Castro.

${ }^{71}$ Historia de los judios, pág. 116. 
por pláticas cortadas a la medida del Evangelio» ${ }^{72}$. La Iglesia no aparece como un sujeto colectivo uniforme que fomente el fanatismo. Incluso acogió a algunos importantes judíos convertidos al cristianismo, como Gerónimo de Santa Fe, Pablo de Santamaría y otros. La importante disputa de Tortosa se realizó en el marco de la Iglesia y fue fundamental para impulsar la conversión de importantes intelectuales judíos convencidos de la superioridad del cristianismo. Frente a la barbarie fanática, una vez más destaca las conversiones masivas y sinceras que se producen cuando se llevaba a cabo una predicación sin presiones. Es decir, algunos eclesiásticos tienen un papel nefasto, pero la Iglesia como tal más bien parece cobijo de conversos o de importantes disputas teológicas que facilitan la conversión. Amador de los Ríos igualmente pondera los esfuerzos de conversión a través de las disputas, aunque también resalta el concilio de Zamora, que por la misma época dicta medidas restrictivas contra los judíos que luego recoge en una bula Benedicto XIII ${ }^{73}$. Para Amador de los Ríos el papado y la plebe serán los principales responsables de endurecimiento de las medidas contra los judíos en el siglo xv, que una Monarquía debilitada tiene que aceptar ${ }^{74}$.

A Castro no le interesa saber si los recién convertidos se habían integrado en la comunidad «española», si su conversión era sincera, etc. Lo único que le importa es dar cuenta del comportamiento de la plebe iracunda y ladrona. Desde 1391, según la Historia de los judíos, la tensión contra los hebreos no dejó de crecer a lo largo del siglo XV. Los pueblos «no cesaban de molestarlos, bien fuesen dirigidos en sus hechos por una piedad bárbara y cruel, bien por el deseo de tomarles, contra toda razón, ley y derecho, las haciendas que heredaron de sus mayores» y que aumentaban con su trabajo. No obstante, las persecuciones a partir del siglo XV no estaban dirigidas contra los judíos, sino contra «los judíos que se habían cristia-

\footnotetext{
${ }^{72}$ Historia de los judios, pág. 85.

${ }^{73}$ Estudios históricos, págs. 103 ss.

${ }^{74}$ R. LÓPEZ-VELA, «Judíos, fanatismo», pág. 85.
} 
nado, y encubriendo sus intentos de oprimirlos y robarlos con decir que judaizaban» ${ }^{75}$. Amador de los Ríos también señala la creciente presión que se ejerce sobre los judíos convertidos, aunque no siempre se realizase violentamente. Es evidente que para ambos la conversión al cristianismo de los hebreos no implicó una integración, dado el rechazo de la plebe hacia todo lo judío ${ }^{76}$.

Según A. de Castro, a pesar de la presión de las prohibiciones, todavía los judíos bajo el reinado de Enrique IV tenían importantes cargos públicos, y los reyes se apoyaban en ellos para cumplir importantes tareas, además de ser las piezas clave del sistema hacendístico. Es decir, la colaboración entre los reyes y los judíos se mantenía plenamente antes de la llegada del matrimonio formado por Isabel y Fernando. Las banderías de los señores contra los reyes, así como los constantes tumultos de la plebe contra los judíos y Enrique IV, habían destrozado a España. Adolfo de Castro no duda en señalar la causa de todos estos males, «los cuales nacieron de los inconsiderados medios de que se sirvieron tan contra razón y justicia los monarcas y pueblos para convertir al cristianismo a los muchos judíos que en estas tierras moraban». La presión y las prohibiciones contra ellos terminaron por impedirles el ejercicio de la medicina y las numerosas profesiones que ejercían, empujándoles a dejar «los judíos el comercio, que eran los únicos o los más que lo frecuentaban y mantenían, y como de esto naciese su destrucción, vino en pos de ella la ruina de la agricultura, quedando el reino sin los dos principales nervios que sustentan el cuerpo de los estados, reducida a la mayor debilidad y a la mayor pobreza» ${ }^{77}$. De esta forma, el fanatismo y la codicia que inspiraron la política contra los judíos acabaron por traer la ruina en la que se encontraba Castilla justo en el momento de acceder al trono Isabel y Fernando.

\footnotetext{
${ }^{75}$ Historia de los judíos, pág. 96.

${ }^{76}$ Estudios históricos, págs. 119 ss.

${ }^{77}$ Historia de los judíos, pág. 101.
} 


\section{INQUISICIÓN Y EXPULSIÓN DE LOS JUDÍOS BAJO LOS REYES CATÓlicos}

En la Historia de los judios, apenas si se dedica atención a la Guerra de Sucesión con la que se inició el reinado de los Reyes Católicos o a sus grandes realizaciones, como la unidad territorial de los reinos de Castilla y de la Corona de Aragón, tal y como hará Amador de los Ríos. Lo que le interesa a Castro es cuanto rodea a la fundación de la Inquisición y la expulsión de los judíos, y a ello se encamina directamente sin prestar atención a otros avatares, por importantes que sean. Cuando el autor publicó su libro sobre los judíos, Prescott ya había sacado su obra sobre el reinado de los Reyes Católicos ${ }^{78}$, y antes de su traducción al castellano en 1848 ya era sobradamente conocido en España y en Europa. Amador de los Ríos demuestra un gran conocimiento de la obra de Prescott y sigue o coincide con buena parte de su visión del reinado. En cambio, Castro no lo cita, y es evidente que ni lo ha leído ni tiene en cuenta su interpretación. No es extraño que haya una notable diferencia en la línea de análisis de A. de Castro respecto a los Reyes Católicos de la que mantiene Amador de los Ríos ${ }^{79}$.

Tal y como había planteado J. A. Llorente ${ }^{80}$, y como continuará señalando el grueso de la historiografía liberal, Castro llevará a cabo una significativa distinción entre los dos componentes del matrimonio. Por un lado, el que logró imponer sus tesis, Fernando el Católico, descrito siguiendo las opiniones de Maquiavelo ${ }^{81}$, que le llevan a trazar un retrato de "político calculador, intrigante, avaricioso, rebosante de ambición personal, carente de principios ni religión». Esto es lo que explica las nefastas decisiones que se

\footnotetext{
${ }^{78}$ W. PrescotT, Historia de los Reyes Católicos Don Fernando y Doña Isabel (Madrid: Imprenta de la Biblioteca del siglo, 1848).

${ }^{79}$ R. LÓPEZ-VELA, «Judíos, fanatismo», págs. 86 ss.

${ }^{80}$ J. A. LLORENTE, Historia crítica de la Inquisición, págs. 125 ss.

${ }^{81}$ Q. SKInNER, Maquiavelo (Madrid 1991).
} 
adoptaron durante el reinado. Por otro lado, una reina Isabel piadosa y buena a la que no gustan las decisiones radicales contra sus súbditos, pero que presionada por las circunstancias, fiada de los eclesiásticos y de su marido, acaba aceptando las peores decisiones. Para el autor, la gloria y la grandeza del reinado pertenece en exclusiva a «Doña Isabel; matrona ilustre, digna en todo de haber nacido en un siglo donde no imperase en la mayor parte de los hombres el bárbaro fanatismo» ${ }^{82}$. No obstante, en flagrante contradicción con esta afirmación, a medida que avanza el relato da cuenta de demasiadas complicidades con su marido. La imagen final que se desprende de Isabel apenas si se diferencia de la de su regio esposo. Frente al mito del glorioso reinado de los Reyes Católicos, los grandes creadores de la nación española ${ }^{83}$, Castro desarrolla una imagen bien distinta, en la que, en la práctica, Isabel queda tan culpada como su regio consorte de haber tomado las más nefastas decisiones que condujeron a sus reinos al desastre.

Castro concede una considerable atención al origen del Tribunal. En el viaje de la reina en 1477 por Andalucía acompañada del cardenal Mendoza, estableció la Santa Hermandad en estas tierras. También escuchó las quejas de fray Alonso de Ojeda, prior de los dominicos, sobre los males que ocasionaban los judíos falsamente convertidos al catolicismo y la necesidad de dar título de inquisidores a los de su orden para proceder contra ellos. Guiada de su natural inclinación a la bondad, la reina no aceptó tal propuesta, y en cambio encomendó a los dominicos la tarea de predicar a estos conversos los principios de la fe. Pero cuando fueron descubiertos importantes núcleos de judaizantes en 1478 , los dominicos se dirigieron al rey para que se instaurase un tribunal de la Inquisición semejante al de Sicilia, que permitía a los inquisidores hacerse con la tercera parte de las haciendas confiscadas. Por supuesto, «esto era, más que devoción,

\footnotetext{
${ }^{82}$ Historia de los judios, pág. 108.

${ }^{83}$ P. Cirujano Marín et al., Historiografía y nacionalismo español, págs. 112 114.
} 
codicia de apoderarse de los muchos y grandes bienes» de los conversos.

Fernando el Católico vio en la posibilidad de apropiarse de parte de los bienes de los judeoconversos la única forma de llenar las arcas públicas que estaban exhaustas por las muchas guerras, y así accedió a la propuesta de los dominicos. El cardenal Mendoza se opuso a esta propuesta, pero no pudo impedir que la reina fuese «vencida de las instancias de su esposo y de toda la frailería dominica que al cebo del interés andaba desalada». Desde estos presupuestos, «¿qué rico podía esperar misericordia de unos hombres que esperaban su muerte o su deshonra para hacer tan sin riesgo tan linda grangería?» ${ }^{84}$. La valoración para A. de Castro es perfectamente evidente: «de esta suerte se podía robar impunemente», o lo que es lo mismo, habían quedado anuladas todas las garantías judiciales. A partir de aquí, la concatenación de los acontecimientos y el comportamiento de los judeoconversos-judíos obedecen a que, «huyendo de los inquisidores (ladrones en poblado), se salían de las ciudades para salvar sus personas y haciendas de la voracidad de aquellos lobos en los reinos extraños» ${ }^{85}$. Es decir, la responsabilidad de cuanto aconteció en aquellos años no fue de la comunidad hebrea, sino de los dominicos, del rey y de unos inquisidores bien apoyados por la plebe.

Citará a J. A Llorente, pero la lectura que ha hecho de su Historia crítica de la Inquisición es superficial e interesada, ignorando o manipulando sin pudor lo que este autor había aportado al conocimiento del Tribunal. Por ejemplo, el establecimiento del Santo Oficio, según A. de Castro, estuvo acompañado por desastres naturales en Andalucía mediante los cuales «la naturaleza» se vengaba de la actuación de «los más bestiales jueces de la Inquisición» ${ }^{86}$. Una constatación que no le impide denunciar la falsedad de la leyenda construida en torno a los milagros a través de los que Dios había

\footnotetext{
${ }^{84}$ Historia de los judíos, págs. 110-111.

${ }^{85}$ Historia de los judios, pág. 120.

${ }^{86}$ Historia de los judios, págs. 115- 116.
} 
dado a conocer la presencia de los convertidos que judaizaban en la clandestinidad ${ }^{87}$. Depende de lo que se trate de demostrar, el mismo argumento resulta una superchería o una prueba inequívoca.

Es cierto que los judíos y los conversos intentaron diversas conspiraciones para evitar la aplicación de la política que les destruía, pero la valoración que ofrece A. de Castro de ellas resulta muy distinta a la que durante siglos predominó avalada por el tratadismo inquisitorial. Para él los judíos y conversos son una especie de luchadores por la libertad ${ }^{88}$, que comenzaron su combate contra una Monarquía tiránica justo cuando ésta comenzaba a dominar el mundo. En este análisis histórico, contrapuesto punto por punto con la visión tradicional, Castro negó que el establecimiento de la Inquisición o la expulsión de los judíos obedeciese a razones religiosas: «Fernando $\mathrm{V}$ jamás pensó en unidades religiosas, porque, si pensara en ellas ¿cómo estaba tan determinado a quitar la obediencia al Papa y hacer cismático al reino?» ${ }^{89}$. En la parte referida a los Reyes Católicos, los judíos son vistos como verdaderos españoles, los oprimidos, aquellos que luchando por su libertad también procuran la de la nación. Evidentemente, es una valoración bastante distinta de la que ofrece en otros capítulos de la obra.

Partiendo de largas y sustanciosas citas de Hernando del Pulgar u otros autores laudatorios con unos reyes que prefieren perder súbditos y comercio antes que permitir la herejía, el autor describe crudamente los costes demográficos y económicos que supuso el establecimiento de la Inquisición. Como es habitual, las citas de los autores de la época que selecciona se convierten en la expresión misma de la realidad, aunque para ello a veces tenga que retorcer un tanto su argumento. En su análisis, el espanto que produjo la instauración del Santo Oficio y la huida consiguiente de judeconversos, llevaron la despoblación a importantes ciudades españolas y terminaron por

\footnotetext{
${ }^{87}$ Historia de los judíos, págs. 118-119.

${ }^{88}$ Historia de los judios, págs. 126 ss.

${ }^{89}$ Historia de los judíos, pág. 154.
} 
destruir el comercio, con las consiguientes pérdidas para el fisco. Es cierto que la Monarquía perdió una importante fuente de ingresos, pero lo compensó sobradamente con las confiscaciones de los bienes de los acaudalados conversos. Siguiendo lo defendido por J. A. Llorente en su Historia crítica de la Inquisición, el autor insiste una y otra vez en que el principal objetivo de Fernando el Católico para fundar el Tribunal fue el apropiarse de los bienes de los conversos ${ }^{90}$. No se trataba de conseguir «el acrecentamiento de la fe, sino reparar con las confiscaciones de los bienes de los herejes, lo exhausto del erario» ${ }^{91}$. Consecuentes con esta política, dice, los inquisidores procedieron en muchas ciudades contra tal número de conversos que no pudieron confiscar sus bienes y tuvieron que contentarse con multas pecuniarias.

A medida que avanza en el análisis de la represión inquisitorial y la expulsión de los judíos, más sorprende la escasa utilización que hace de la Historia crítica de la Inquisición de Llorente. Es cierto que antes de que A. de Castro diese su libro a la imprenta, algunos autores habían desmontado buena parte de las exageraciones de Llorente ${ }^{92}$, pero dudo mucho de que quien ni tan siquiera hubiese leído con atención la obra de Llorente, o que hubiese consultado otros libros escritos en alemán u otras lenguas, que comenzaron a ser citados bastantes años después por los historiadores españoles mejor informados. Con unas pocas crónicas, especialmente la de Hernando del Pulgar, A. de Castro compone un relato tremendista en el que su gran preocupación es ofrecer al lector otra visión del «glorioso» reinado de los Reyes Católicos. Aquí es donde se percibe en toda su dimensión la perspectiva liberal de la historia nacional que propone el autor a un liberalismo que mayoritariamente contempla el pasado desde posiciones más próximas a las de Amador de los Ríos.

\footnotetext{
${ }^{90}$ J. A. LLORENTE, Historia crítica de la Inquisición, pág. 125.

${ }^{91}$ Historia de los judios, págs. 120-121.

${ }^{92}$ Ch. Hefele, El cardenal Jiménez Cisneros y la Iglesia española a fines del siglo XV y principios del XVI (Barcelona 1869). La primera edición en alemán es de 1844.
} 
Lo que le preocupa es reducir a una clara y precisa coherencia cuanto ocurrió en torno a los judíos durante los años de los Reyes Católicos, teniendo en cuenta que esta es la pieza clave que explica el conjunto del reinado. Es la otra visión de las glorias de España y del heroísmo de los españoles. Es verdad, señala, que durante este reinado se conquistó Granada, Navarra y las Islas Canarias, que se descubrió el Nuevo Mundo, que se consiguió Nápoles, etc., pero los historiadores, ya sea por ignorancia o cobardía, no han contado cuál fue el precio de todas estas adquisiciones. Dar cuenta de la coherencia de estas glorias y sus consecuencias supone explicar de forma distinta a la habitual las razones de la grandeza de España en el mundo durante los siglos siguientes, descubrir las entretelas de la historia nacional. A esta tarea dedica su esfuerzo central A. de Castro en su Historia de los judíos.

En su insistencia por situar en el centro a los judeoconversos-judíos, entiende la expulsión de 1492 en los mismos términos económicos que la creación del Tribunal. Se les expulsó porque Fernando el Católico no quería pagar su fuerte deuda con ellos, dados los empréstitos que le habían concedido los judíos castellanos para la Guerra de Granada ${ }^{93}$. No dedica especial atención a esta guerra, pero deja claro que si se pudo llevar a cabo fue gracias a la financiación de los judíos y, por tanto, la gran gesta nacional que significó el final de la Reconquista se lo debe casi todo a ellos. Apenas acabada la guerra, viendo que no podía afrontar el pago de la deuda, decretó su expulsión, de forma que o bien se deshacía de sus acreedores, o «bien obligando a muchos de los judíos a convertirse a la fe, para que luego la Inquisición formase proceso a los más acaudalados con que todas sus riquezas pasasen al fisco». Un plan maquiavelico ejecutado bajo la atenta mirada y consejo de ese «bellaco» que era el Inquisidor General Torquemada. Muchos judíos se convirtieron «por temor a las incomodidades del viaje y por el mucho amor que tenían a su patria» ${ }^{94}$.

\footnotetext{
${ }^{93}$ Historia de los judíos, págs. 134-135.
}

${ }^{94}$ Historia de los judios, págs. 136 y 145. 
Fernando el Católico fue un rey carente de escrúpulos, capaz de cualquier decisión con tal de imponer sus objetivos, por mucho que los costes humanos y sociales sean la negación misma del cristianismo que dice defender. A. de Castro lo explica con nitidez en un párrafo: «En las confiscaciones estribaba todo el gran celo por acrecentamiento de la religión cristiana en sus tierras y señoríos; en las confiscaciones aquel deseo de mantener en sus estados la unidad religiosa, acción que tanto nos han cacareado sus panegiristas. Es cierto que las aplicaba a conquistar otras tierras; pero empobreciendo las suyas; y es cierto también que fue quien abrió la puerta a sus sucesores para que con la ruina del comercio y de la labranza en España, llevase a los reinos extraños la fama del valor español; el cual, como sólo se ejercitó en su daño y sólo en guerras injustísimas, no consiguió más que la admiración y la envidia de los vencidos y opresos, y de hacerse entonces aborrecidísimo en todas las provincias del orbe que sintieron el yugo de sus armas, y el tiránico gobierno de sus reyes» ${ }^{95}$. En una palabra, el engrandecimiento de España durante el reinado de los Reyes Católicos fue resultado de intereses espurios que trajeron aparejada la miseria y la ruina de su propio pueblo. A corto plazo, fue mucha la gloria de las conquistas, pero a largo plazo el coste fue la ruina, y «en vez de hacer un verdadero servicio a la nación española, le hicieron multitud de daños que aun hoy estamos pagando» ${ }^{96}$. Castro reiterará frecuentemente uno de los lugares comunes de los autores liberales: cuanto ocurrió a finales del siglo XV o en el XVI es la causa de la lamentable situación de la España de mediados del siglo XIX.

Los judíos que se fueron tuvieron que malvender sus bienes a un precio ridículo, iniciando un viaje incierto. Unos camino de Fez, donde fueron objeto de todo tipo de abusos por parte de «aquella bárbara canalla en todo igual, menos en la religión, a los bestiales

${ }^{95}$ Historia de los judíos, págs. 130-131.

${ }^{96}$ Historia de los judíos, pág. 154. 
jueces del Santo Oficio» ${ }^{97}$. Otros salieron camino de Italia u otros puntos de Europa o del Mediterráneo. De entre todos estos destinos, va a dedicar singular atención a Portugal, donde se asentaron la mayoría de los que salieron. En este reino también se fundó la Inquisición, pero en 1577 los conversos y la Corona llegaron, según A. de Castro, a un acuerdo sobre las confiscaciones de los procesados que facilitó el que los judíos ocultos que quedaban en España pasasen a Portugal. Dos actuaciones inquisitoriales bien distintas que en la obra de Castro adquieren un evidente contraste: la una no es tan negativa, la portuguesa, y la otra es nefasta, la española.

Las consecuencias del establecimiento de la Inquisición y la expulsión de los judíos es comparada por A. de Castro con la destrucción del Templo de Jerusalén. Los efectos de la expulsión han marcado la historia de la nación hasta su propio presente. Sin embargo, según él, esta política antievangélica, lejos de desarraigar la religión judaica, consiguió su fortalecimiento y su expansión hasta la Guerra de la Independencia, porque «mientras más autos de fe, más muertes y más infamias de linaje se hacían por los inquisidores, más personas judaizaban» ${ }^{98}$. El ejemplo de los mártires que salían en los autos de fe constituía un acicate que llevaba a muchos cristianos viejos al judaísmo, de forma que la represión inquisitorial logró lo contrario de lo que se proponía. Para fundamentar tan insólita afirmación, opuesta a los análisis de Llorente, da cuenta de algunos autos de fe deslavazados que tan sólo prueban su existencia. Su empeño es demostrar al lector que los inquisidores han sido «el azote del cristianismo», que con la represión religiosa se logra lo contrario de lo que se pretende. Para ello recurre a todo tipo de manipulaciones, sin importarle que apenas tenga datos en que apoyarse o que sea el único que sostiene tan sorprendente afirmación.

Si la represión tan sólo logró fortalecer el judaísmo, sí tuvo, en cambio, efectos devastadores para el desarrollo económico e intelec-

${ }^{97}$ Historia de los judíos, pág. 147.

${ }^{98}$ Historia de los judíos, pág. 220. 
tual de la nación. No sólo se expulsaron o quemaron a los principales agentes comerciales y financieros, sino que también siguieron el mismo camino gran número de intelectuales. El resultado fue que «todo el comercio se encontraba en manos de extranjeros, de suerte que mientras ellos se enriquecían, España se iba enflaqueciendo y debilitando en gran manera» ${ }^{99}$. Según A. de Castro, cualquiera que supiese lenguas orientales se convirtió en una persona sospechosa, de forma que numerosos hebraístas acabaron en las cárceles inquisitoriales, como Fray Luis de León, Cantalapiedra, Grajal, etc. Anteriormente, el intento de Nebrija de llevar a cabo una revisión de la traducción de la Vulgata llevó a que le denunciasen al Santo Oficio y a que el Inquisidor Deza le arrebatase sus notas y libros para impedirle proseguir su tarea. El resultado final de todo ello fue que los teólogos temieron ser procesados por cuestionar la Vulgata: unos se refugiaron en el silencio, mientras que otros, «huyendo del bando de la verdad, se pasaron al bando de la multitud; porque entre ella solamente se prometían respirar sin contradicción ni sobresaltos» ${ }^{100}$. La gran triunfadora es la multitud, junto a los Reyes Católicos, más que los reyes de la dinastía austriaca, a los que apenas nombra.

\section{CONCLUSIONES}

El antisemitismo estaba en pleno proceso de renovación en la primera mitad del ochocientos. En los años cuarenta de este siglo continuaba siendo una aventura intelectual bastante arriesgada escribir una historia nacional que explicase el pasado de los españoles con arreglo a los principios liberales, adentrándose en terrenos (los judíos, por ejemplo) que durante siglos tan sólo habían podido explicarse desde la ortodoxia inquisitorial. Este fue el propósito de Adolfo de Castro con su Historia de los judíos. Se trata de una obra destinada a demostrar los constantes errores que han dominado la historia nacio-

${ }^{99}$ Historia de los judios, pág. 166.

${ }^{100}$ Historia de los judíos, págs. 155 ss. La cita corresponde a pág. 165. 
nal por haberse aplicado una política antiliberal, cuyo exponente más claro fue la persecución y expulsión de los judíos. Indudablemente, fue una obra pionera en este terreno, aunque los logros queden bastante lejos de sus pretensiones.

Su análisis historiográfico resulta bastante endeble, pero sus conclusiones políticas son claras: los judíos han sido el antecedente lejano de los liberales, ambos comparten la incomprensión y la persecución por parte de la mayoría. Con esta premisa construye un libro dominado por una visión catastrofista de la historia nacional. Es significativo que a lo largo de su relato no se encuentre algún período realmente positivo en la historia de España, y esto se manifiesta en esa constante presión contra los judíos. Es más, cuanto mayor sea el castigo contra esta minoría, peor le irá a España. Es decir, los propios españoles son los responsables de sus desgracias, y con su acción fanática provocaron más y más la ruina de su nación. El fanatismo y las persecuciones aparecen así como las grandes causas de una historia llena de desastres que ha acabado por precipitar a España en el atraso y la barbarie. Evidentemente, el libro de Castro está bastante lejos de la historiografía que comenzaba a hacerse en la época. Su libro más bien parece una inversión de las interpretaciones que el grueso de la historiografía liberal comenzaba a producir, empeñada, como estaba, en contar las grandes realizaciones patrias. Evidentemente, dentro del liberalismo, la opción que planteará Castro resultó claramente minoritaria.

Por lo que da a entender, más que por la precisión de sus análisis, parece deducirse que los judíos no fueron españoles plenos, entre otras cosas porque las constantes persecuciones no se lo han permitido. Pueblo desafecto e inclinado a la traición, ha reaccionado al acoso sufriendo con resignación en algunos momentos, aunque cuando ha intentado algo ha sido de forma taimada y llena de odio a los españoles. En su libro los judíos aparecen como un pueblo compacto dentro de un pueblo español igualmente compacto. Son una nación dentro de otra nación, sin que en ningún caso defina su identidad nacional y religiosa. En la Historia de los judíos, estos son lo mejor 
que ha tenido España, a pesar de sus bajas pasiones. ¿Estaría Castro próximo a entender este fenómeno como un rechazo racial hacia los judíos por parte de unos españoles siempre identificados como católicos fanáticos? Creo que no, que la interpretación de A. de Castro al respecto no tiene nada que ver con problemas raciales, sino con las pasiones incontrolables y el fanatismo de la plebe que ha elegido a los judíos como objeto de su odio, como presa fácil para practicar la rapiña impunemente. La antiespaña son los mismos españoles, mientras que en bastantes pasajes se da a entender que los judíos son lo mejor de España. No obstante, esto no le impide mantener gran parte de los tópicos de la leyenda antijudía. Con todas sus contradicciones, Castro hará una clara reivindicación de la presencia judía en España desde la historia frente a los ultramontanos.

Para Castro, la práctica del catolicismo desde los concilios de Toledo, en el caso de gran parte de los reyes y de los obispos y órdenes religiosas, ha sido sinónimo de fomento del fanatismo. No obstante, los reyes, o los mismos obispos, no han sido los más fanáticos. Pronto la plebe se apropió del mensaje fanático y la intolerancia ha guiado desde entonces las pasiones de la multitud. El resultado de esta valoración es un libro dedicado a combatir el catolicismo fanático y visceral que hasta entonces, según Castro, había definido a los españoles a lo largo de la historia. La irracionalidad, la crueldad, la violencia, la superstición son los componentes de su fanatismo, conduciéndoles a un heroísmo estéril y fácilmente manipulable por reyes maquiavélicos. Esta «muchedumbre» es la gran triunfadora de la historia patria, y su catolicismo fanático, la esencia de la nación.

Plebe irracional y fanatismo son una combinación explosiva en la Historia de los judíos que produce inevitablemente todo tipo de motines y algaradas que dan al traste con cualquier política racional y liberal. La actuación o la presión de la plebe siempre produce en la Monarquía, cuando ésta se deja influir, decisiones «impolíticas». Lo importante es la crítica al pueblo fanático y a quienes se adaptan a él o manipulan sus pasiones para conseguir sus objetivos, como 
hace Fernando el Católico. En las páginas que dedica a los Reyes Católicos se aprecia con perfecta nitidez la naturaleza esencialmente panfletaria y no historiográfica de la Historia de los judios, pero no se le puede negar una cierta coherencia a su planteamiento: los Reyes Católicos son los responsables de la decadencia de la nación por haber creado la Inquisición y haber expulsado a los judíos. Una visión sobre el particular que resulta más fácil de defender que los intentos de Amador de los Ríos por exculpar a estos reyes de estas decisiones, aunque historiográficamente el análisis de este último sea muy superior. Es cierto que la historiografía española o extranjera más rigurosa no prestará gran atención a A. de Castro, pero éste logrará un notable peso en las corrientes liberales más anticlericales que llevarán a cabo una interpretación de la historia hispana desde la renovación de la leyenda negra. En ella, la plebe fanática tendrá el máximo protagonismo, junto a algunos reyes o eclesiásticos, también fanáticos, que han sabido manipular o encauzar la energía irracional y retardataria de la muchedumbre. 


\section{RESUMEN}

Tras la abolición de la Inquisición española, hubo un importante intento de recuperar la huella de la presencia judía en España por parte de los historiadores liberales. Adolfo de Castro defenderá la importancia de la aportación judía frente a quienes renovaban la propaganda antijudía equiparándoles a masones y liberales, aunque potenciará otros tópicos en los que los judíos son el centro de la historia nacional. Para Castro, el declive de España es la consecuencia de la combinación de los procesos de la opresión y expulsión de los judíos. En su visión, los judíos son idealizados como expresión de lo mejor de España frente a un pueblo fanático e intolerante.

PALABRAS ClAVE: Adolfo de Castro, siglo XIX, historiografía liberal, historia de los judíos.

\section{SUMMARY}

After the abolition of the Spanish Inquisition there was a revival of the interest in the history of the deep cultural and social mark left by the Jews in Spain. Adolfo de Castro developed a new focus on the subject avoiding the relationship of Jews with masons and liberals as fashioned and diffused by conservative propaganda. He stressed the positive role played by the Jews in the history of Spain. He considered that the progressive decline of Spain happened as a result of a combination of the processes of oppression and eventual expulsion of the Jews. According to Castro, the idealization of the Jews was then conceived as standing opposite to popular prejudices and intolerance.

KEYWORDS: Adolfo de Castro, $19^{\text {th }}$ century, liberal historiography, history of the Jews. 